\title{
ANALISIS KESULITAN BELAJAR MATEMATIKA PADA TOPIK LOGIKA DI SMK MUHAMMADIYAH 3 KLATEN UTARA
}

\author{
Aji Permana Putra \\ Pendidikan Matematika, Universitas Cokroaminoto Yogyakarta \\ Jl. Perintis Kemerdekaan, Gambiran, Umbulharjo, Kota Yogyakarta 55161 \\ Email: putrapermanaaji@gmail.com
}

\begin{abstract}
ABSTRAK
Matematika adalah dasar dari semua ilmu, salah satu yang ditekankan dalam pembelajaran matematika adalah logika berpikir. Dalam pembelajaran di SMK logika matematika merupakan materi yang penting karena logika mendasari berpikir matematika, kenyataanya masih banyak siswa yang kesulitan dalam mempelajari materi logika matematika, sehingga perlu dilakukan analisis untuk mengetahui kesulitan belajar siswa dalam pembelajaran matematika terutama topik matematika. Selain itu faktor penyebab dari kesulitan belajar matematika juga perlu dianalisis dilihat dari faktor fisiologis, sosial, emosional, intelektual dan pedagogik, sehingga didapatkan solusi yang tepat untuk mengatasi kesulitan belajar matematika terutama topik logika matematika.
\end{abstract}

Kata kunci: kesulitan belajar matematika, penyebab kesulitan belajar matematika

\begin{abstract}
Mathematics is the basis of all sciences, one that is emphasized in learning mathematics is logic thinking. In learning in vocational mathematics mathematics is an important material because logic underlies mathematical thinking, in fact there are still many students who have difficulty in learning mathematical logic material, so it needs to be analyzed to find out the learning difficulties of students in learning mathematics especially mathematics topics. In addition, the causative factors of learning difficulties in mathematics also need to be analyzed in terms of physiological, social, emotional, intellectual and pedagogical factors, so that the right solution to overcome mathematical learning difficulties, especially the topic of mathematical logic.
\end{abstract}

Keywords: learning difficulties mathematics, the causes of learning difficulties mathematics

\section{PENDAHULUAN}

Matematika merupakan salah satu cabang ilmu yang sangat penting. Hampir setiap disiplin ilmu menggunakan ilmu matematika. Dari jenjang yang paling rendah hingga paling tinggi, dari siswa SD sampai mahasiswa, hampir semua mempelajari matematika. Salah satu jenjang yang mempelajari Matematika adalah Sekolah Menengah Kejuruan (SMK). Walaupun SMK lebih mengutamakan praktek daripada teori tetapi matematika merupakan mata pelajaran yang sangat 
penting, karena disamping matematika merupakan salah satu mata pelajaran UNAS, matematika juga banyak digunakan untuk perhitungan dalam kejuruan.

Pola pikir masyarakat selama ini tentang SMK yang berpendapat bahwa di SMK tidak mementingkan teori tetapi praktek yang diutamakan menyebabkan terbentuknya pola pikir anak SMK yang kurang motivasi ketika mempelajari mata pelajaran yang tidak menggunakan praktek. Anak SMK selalau bersemangat ketika mata pelajaran praktek karena pola pikir mereka sudah terbentuk bahwa SMK pasti banyak praktek, orientasi mereka sebagian besar adalah dunia kerja sehingga banyak siswa SMK yang mengbaikan mata pelajarain teori. Padahal dasar dari semua praktek adalah teori. Dan dasar dari semua ilmu adalah matematika. Tetapi pada kenyataannya matematika merupakan salah satu mata pelajaran yang dianggap sulit oleh siswa selama ini, sehingga hal ini semakin mendukung siswa SMK mempunyai motivasi yang rendah ketika mempelajari matematika.

Salah satu pokok bahasan Matematika jenjang SMK adalah logika matematika. Logika matematika merupakan pokok bahasan Matematika jenjang SMK yang sangat penting, karena disamping logika matematika sering keluar dalam UNAS, logika matematika juga sering keluar dalam tes potensi akademik (TPA) pada tes kerja dan bermanfaat dalam kehidupan sehari-hari. Pada dasarnya tujuan utama dari pembelajaran logika matematika adalah mengembangkan pola pikir logis siswa dalam menyikapi persoalan hidup sehari-hari. Sehingga mempelajari dan menguasai materi logika matematika sangat penting. Sebenarnya materi logika matematika merupakan materi yang paling sedikit perhitungan matematikanya, akan tetapi kenyataannya banyak siswa yang masih mengalami kesulitan. Terlihat dari hasil ulangan harian pada bab logika matematika banyak siswa yang memperoleh nilai di bawah KKM yaitu dibawah 75 . Sehingga perlu dilakukan penelitian untuk mengetahui kesulitan-kesulitan dalam bab logika matematika. Berdasarkan ulangan harian bab logika matematika, siswa kelas X SMK Muhammadiyah 3 Klaten Utara masih banyak yang tidak mampu menjawab soal logika matematika sederhana seperti mencari kalimat yang ekuivalen, nilai kebenaran, penarikan kesimpulan dll. Berdasarkan permasalahan tersebut perlu dicari kesulitan apa saja yang dialami siswa khususnya siswa kelas X SMK Muhammadiyah 3 Klaten Utara dalam mempelajari logika matematika. Rumusan Masalah:

1. Kesulitan-kesulitan apa yang dialami siswa SMK dalam mempelajari topik Logika Matematika? 
2. Kesulitan belajar matematika dilihat dari faktor penyebab apa saja?

3. Alternatif pemecahaan apa yang dapat digunakan untuk mengatasi kesulitan siswa dalam mempelajari topik Logika Matematika?

\section{A. Logika Matematika}

Secara etimologis, logika berasal dari kata Yunani 'logos' yang berarti kata, ucapan, pikiran secara utuh, atau bisa juga berarti ilmu pengetahuan berdasarkan pendapat Kusumah, (1986) di http://id.shvoong.com. Dalam arti luas, logika adalah suatu cabang ilmu yang mengkaji penurunan-penurunan kesimpulan yang sahih (valid, correct) dan yang tidak sahih (tidak valid, incorrect). Proses berpikir yang terjadi di saat menurunkan atau menarik kesimpulan dari pernyataan-pernyataan yang diketahui benar atau dianggap benar itu biasanya disebut dengan penalaran (reasoning). Logika, penalaran, dan argumentasi sangat sering digunakan di dalam kehidupan nyata sehari-hari, di dalam mata pelajaran matematika sendiri maupun mata pelajaran lainnya. Karenanya, Logika Matematika ini sangat berguna bagi siswa, karena di samping dapat meningkatkan daya nalar, namun dapat langsung diaplikasikan di dalam kehidupan nyata mereka sehari-hari maupun ketika mempelajari mata pelajaran lainnya. Tujuan pembelajaran Logika Matematika pada dasarnya adalah agar para siswa dapat menggunakan aturan-aturan dasar Logika Matematika untuk penarikan kesimpulan.

\section{B. Kesulitan Belajar Matematika}

Kesulitan belajar tidak dialami hanya oleh siswa yang berkemampuan di bawah rata-rata tetapi dapat dialami oleh siswa dengan tingkat kemampuan manapun dari kalangan atau kelompok manapun. Tingkat dan jenis sumber kesulitannya beragam. Mengutip Brueckner dan Bond, Cooney, Davis, dan Henderson (1975) dalam Widdiharto (2004) mengelompokkan sumber kesulitan itu menjadi lima faktor, yaitu:

a. Faktor Fisiologis

Kesulitan belajar siswa dapat ditimbulkan oleh faktor fisiologis. Hal ini antara lain ditunjukkan oleh kenyataan bahwa persentase kesulitan belajar siswa yang mempunyai gangguan penglihatan lebih dari pada yang tidak mengalaminya.

b. Faktor Sosial

Hubungan orang tua dengan anak, dan tingkat kepedulian orang tua tentang masalah belajarnya di sekolah, merupakan faktor yang dapat memberikan kemudahan, atau sebaliknya menjadi faktor kendala bahkan penambah kesulitan belajar siswa. Selain itu ekonomipun 
merupakan faktor, baik positif maupun negatif. Siswa yang mengalami masalah sosial di rumahnya biasanya dari kalangan keluarga yang kurang menaruh perhatian pada perkembangan anaknya. Hal ini mungkin akibat dari kepedulian yang rendah terhadap belajar anak/siswa, permasalahan tersebut dapat terjadi baik dari kalangan yang ekonominya sudah mapan maupun ekonominya masih lemah. Faktor sosial di dalam dan di luar kelas dalam lingkungan sekolah juga berpengaruh terhadap kelancaran atau kesulitan belajar siswa. Secara umum siswa yang terlalu tertutup atau terlalu terbuka mungkin adalah siswa yang mengalami masalah sosial di rumah atau tekanan dari teman atau mungkin orang tuanya. Jadi lingkungan belajar di sekolah juga merupakan salah satu faktor sosial kesulitan belajar siswa.

c. Faktor Emosional

Siswa yang sering gagal dalam matematika lebih mudah berpikir tidak rasional, takut, cemas, benci pada matematika. Jika demikian maka hambatan itu dapat "melekat" pada diri anak/siswa. Masalah siswa yang termasuk dalam faktor emosional dapat disebabkan oleh:

1) Obat-obatan tertentu, seperti obat penenang, ekstasi, dan obat lain yang sejenis.

2) Kurang tidur.

3) Diet yang tidak tepat.

4) Hubungan yang renggang dengan teman terdekat.

5) Masalah tekanan dari situasi keluarganya di rumah.

Mengutip Teaching About Drug Abuse (1972:22-26), Cooney dkk (1975) dalam p4tkmatematika.org

d. Faktor Intelektual

Siswa yang mengalami kesulitan belajar disebabkan oleh faktor intelektual, umumnya kurang berhasil dalam menguasai konsep, prinsip, atau algoritma, walaupun telah berusaha mempelajarinya. Siswa yang mengalami kesulitan mengabstraksi, menggeneralisasi, berpikir deduktif dan mengingat konsep-konsep maupun prinsip-prinsip biasanya akan selalu merasa bahwa matematika itu sulit. Siswa demikian biasanya juga mengalami kesulitan dalam memecahkan masalah terapan atau soal cerita..

e. Faktor Pedagogis

Di antara penyebab kesulitan belajar siswa yang sering dijumpai adalah faktor kurang tepatnya guru mengelola pembelajaran dan menerapkan metodologi. Misalnya guru masih kurang memperhatikan kemampuan awal yang dimiliki siswa, guru langsung masuk ke materi 
baru. Ketika terbentur kesulitan siswa dalam pemahaman, guru mengulang pengetahuan dasar yang diperlukan. Kemudian melanjutkan lagi materi baru yang pembelajarannya terpenggal. Jika ini berlangsung dan bahkan tidak hanya sekali dalam suatu tatap muka, maka akan muncul kesulitan umum yaitu kebingungan karena tidak terstrukturnya bahan ajar yang mendukung tercapainya suatu kompetensi.

\section{PEMBAHASAN}

\section{A. Pemilihan Subjek dan Instrumen}

1. Subyek Penelitian

Subyek dalam penelitian ini adalah siswa kelas X Otomotif 4 SMK Muhammadiyah 3 Klaten Utara. Dipilih kelas X Otomotif 4 karena berdasarkan ulangan harian bab logika matematika kelas X Otomotif 4 rata-rata hasil ulangannya paling rendah dibandingkan kelas $\mathrm{X}$ lainnya. Dari semua siswa kelas X Otomotif 4 diambil sampel 1 siswa secara acak yaitu Joko Mursito.

2. Instrumen

Instrumen yang digunakan untuk mengidentifikasi kesulitan siswa dalam penelitian ini adalah 2 soal berikut.

SOAL:

1. Premis 1 : Jika hari ini Jum'at maka semua siswa memakai pakaian olahraga.

Premis 2 : Ada siswa tidak memakai pakaian olahraga atau semua siswa mengikuti senam.

Tentukan:

a. Kalimat implikasi yang ekuivalen dari premis 2

b. Kesimpulan dari kedua premis

2. Isilah tabel kebenaran di bawah ini:

\begin{tabular}{|l|c|c|c|c|c|l|l|}
\hline $\mathrm{p}$ & $\mathrm{q}$ & $\sim \mathrm{p}$ & $\sim \mathrm{q}$ & $\sim \mathrm{p} \wedge \mathrm{q}$ & $\mathrm{p} \vee \sim q$ & $\begin{array}{l}(\sim \mathrm{p} \wedge \mathrm{q}) \\
\rightarrow p\end{array}$ & $\begin{array}{l}(\mathrm{p} \vee \sim q) \\
\leftrightarrow\end{array}$ \\
\hline $\mathrm{B}$ & $\mathrm{B}$ & & & & & & \\
$\mathrm{B}$ & $\mathrm{S}$ & & & & & & \\
$\mathrm{S}$ & $\mathrm{B}$ & & & & & & \\
$\mathrm{S}$ & $\mathrm{S}$ & & & & & & \\
\hline
\end{tabular}




\section{Jawaban Tertulis dan Analisisnya}

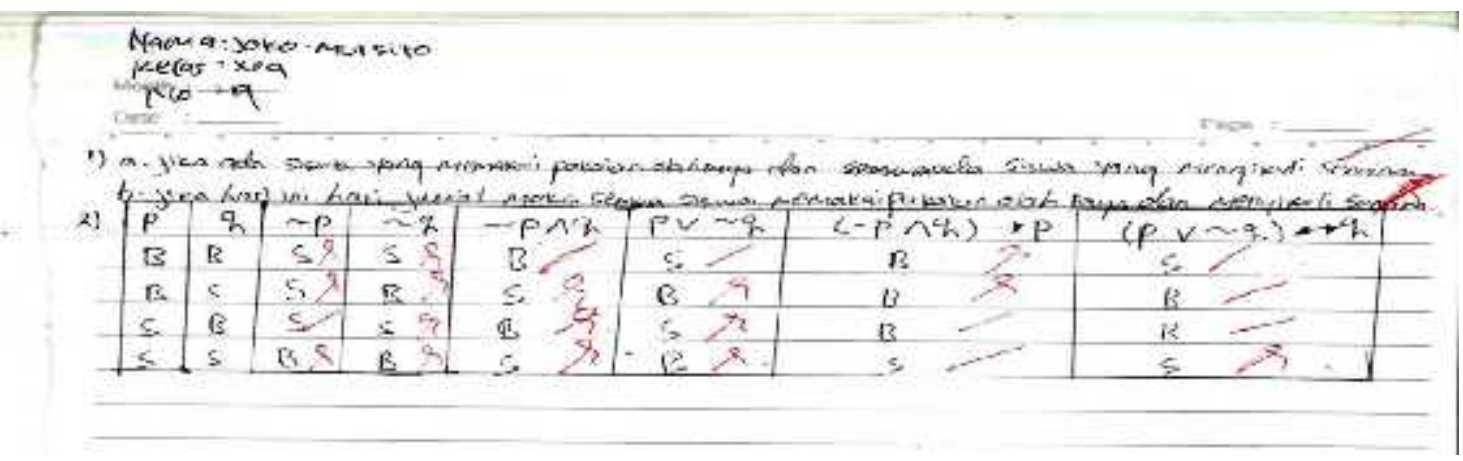

\section{Analisis kesalahan}

No. 1.a.

Siswa menjawab bentuk kalimat yang ekuivalen dengan bentuk disjungsi ke dalam bentuk implikasi sudah benar tetapi untuk kalimat pertama (Ada siswa yang memakai pakaian olahraga) dalam bentuk implikasi tersebut masih salah, seharusnya kalimat pertama diingkarkan terlebih dahulu. Akibatnya terjadi kesalahan dalam mengubah bentuk kalimat majemuk disjungsi ke dalam bentuk implikasi.

No. 1.b.

Siswa menjawab kesimpulan dari kedua premis sudah benar dalam bentuk implikasi, kemungkinan siswa sudah mengetahui pengambilan kesimpulannya menggunakan silogisme. Tetapi untuk kalimat kedua (semua siswa memakai pakaian olahraga dan senam) dalam bentuk implikasi tersebut masih salah, seharusnya kalimat kedua dalam bentuk kalimat tunggal (semua siswa memakai pakaian olahraga) bukan dalam bentuk kalimat konjungsi. Akibatnya terjadi kesalahan dalam pengambilan kesimpulan dari 2 premis menggunakan silogisme, kemungkinan karena kesalahan soal 1a sehingga pengambilan kesimpulannya juga salah.

No. 2.

- Siswa menjawab 7 soal benar dan 1 soal salah dalam menentukan ingkaran dari nilai kebenaran, kemungkinan karena siswa kurang teliti.

- Siswa menjawab 3 soal benar dan 1 soal salah tentang nilai kebenaran bentuk konjungsi, 1 dari jawaban soal yang benar berawal dari jawaban yang salah dari ingkaran nilai kebenaran, dari jawaban soal tersebut diduga siswa hanya hafal sebagian nilai kebenaran konjungsi.

- Siswa menjawab 3 soal benar dari 4 soal tentang nilai kebenaran disjungsi, kemungkinan siswa kurang teliti atau sedikit lupa tentang nilai kebenaran disjungsi. 
- Siswa menjawab 2 soal benar dari 4 soal tentang nilai kebenaran implikasi, kemungkinan kesalahan tersebut karena siswa sebagian lupa tentang nilai kebenaran implikasi. Dan siswa menjawab benar nilai kebenaran implikasi pada soal pertama nilai kebenaran implikasi padahal nilai kebenaran untuk $\sim \mathrm{p} \wedge \mathrm{q}$ salah.

- Siswa menjawab 1 soal benar dari 4 soal nilai kebenaran biimplikasi, kemungkinan siswa lupa dalam menentukan nilai kebenaran biimplikasi.

\section{B. Hasil Wawancara dan Analisisnya}

Untuk melihat lebih jauh kesulitan belajar topik Logika matematika kelas X SMK Muhammadiyah 3 Klaten Utara, dilakukan wawancara terhadap siswa sebagai berikut:

Guru: Bagaimana keadaanmu ketika mengerjakan soal tadi?

Siswa : Agak gugup

Guru : Tau arti ekuivalen?

Siswa : pernah tau tapi lupa

Guru : Apa kamu belum paham tentang kalimat yang ekuivalen?

Siswa : Gak paham

Guru : kalau $p \rightarrow q$ ekuivalen dengan apa?

Siswa : lupa

Guru : kalau premis 2 saya ganti "Jika semua siswa memakai pakaian olahraga maka semua siswa mengikuti senam. Kesimpulannya apa?

Siswa : Jika hari ini jum'at maka semua siswa pakai pakaian olahraga dan semua siswa senam.

Guru $\quad: P_{1}: p \rightarrow q$

$$
P_{2}: q \rightarrow r
$$

Siswa $: p \rightarrow q \wedge r$

Guru : Apa kamu belum paham tentang ingkaran?

Siswa : paham, benar ingkaran salah, salah ingkaran benar.

Guru : Kalau konjungsi apa kamu sudah paham?

Siswa : Belum

Guru $: B \wedge B, B \wedge S, S \wedge B, S \wedge S$ nilai kebenarannya?

Siswa : Benar, salah, salah, salah

Guru : Kalau disjungsi apa kamu paham?

Siswa : Belum

Guru : $S \vee S, S \vee B, B \vee S, B \vee B$ nilai kebenarannya?

Siswa : Salah, benar, benar, salah.

Guru : Cara mengingat bagaimana?

Siswa : Cuma kira-kira saja

Guru : Kalau implikasi apa kamu paham? 
Siswa : Belum

Guru : $B \rightarrow S, S \rightarrow S, B \rightarrow B, S \rightarrow B$ nilai kebenarannya?

Siswa : Salah, salah, benar, salah

Guru : Kalau biimplikasi apa km paham?

Siswa : Belum

Guru : $B \Leftrightarrow B, B \Leftrightarrow S, S \Leftrightarrow B, S \Leftrightarrow S$ nilai kebenarannya?

Siswa : Benar, salah, salah, benar.

Analisis jawaban siswa:

1) Untuk no 1. a. Siswa tidak tahu tentang konsep ekuivalen apalagi harus mencari kalimat yang ekuivalen. Siswa kesulitan dalam mendefinisikan ekuivalen dan kalimat yang ekuivalen. Untuk No. 1 b. Siswa kesulitan dalam menarik kesimpulan dengan silogisme dan siswa semakin kesulitan ketika menarik kesimpulan dengan silogisme dan divariasi dengan kalimat yang ekuivalen dengan implikasi.

2) Untuk soal no 2 siswa sudah tahu tentang ingkaran nilai kebenaran, nilai kebenaran konjungsi dan biimplikasi, tetapi siswa belum begitu menguasai tentang nilai kebenaran disjungsi dan implikasi.

\section{Pembahasan Hasil Jawaban Tertulis dan Wawancara}

1. Kesulitan

Berdasarkan hasil tes dan wawancara, terdapat beberapa kesulitan yang dihadapi siswa dalam topik logika matematika antara lain:

a. Kesulitan dalam menentukan ekuivalensi kalimat majemuk.

Berdasarkan hasil tes dan wawancara, semua siswa kesulitan dalam menentukan definisi dari ekuivalen dan kesulitan dalam menentukan kalimat yang ekuivalen dengan bentuk kalimat disjungsi

b. Kesulitan dalam menentukan kesimpulan dari 2 premis

Dari hasil tes tertulis dan wawancara, dua siswa mengalami kesulitan dalam penarikan kesimpulan dari dua premis dengan silogisme, mereka tahu kesimpulannya dalam bentuk kalimat implikasi tetapi mereka menggabungkan semua kalimat tunggal yang ada pada kedua premis dalam kesimpulan tersebut.

c. Kesulitan dalam menentukan nilai kebenaran kalimat majemuk

Dari hasil tes tertulis dan wawancara siswa mengalami kesulitan dalam menentukan nilai kebenaran kalimat majemuk, karena mereka menghafal satu persatu dalam menentukan 
nilai kebenaran kalimat majemuk tersebut sehingga besar kemungkinan untuk lupa sehingga menjawab soal ada yang hanya mengira-ira.

2. Solusi

a. Memberikan pengertian kepada siswa apabila dalam logika matematika tidak dihafalkan satu persatu tetapi perlu pemahaman konsep logika matematika.

b. Memberikan latihan-latihan soal yang lebih banyak tentang pengambilan keputusan dari dua premis.

c. Memberikan alternatif untuk memudahkan siswa memahami konsep nilai kebenaran dengan menghubungkan dengan kalimat dalam kehidupan sehari - hari yaitu:

1. Konjungsi ( "dan").

Keduanya benar maka nilai kebenarannya benar selain itu salah. Nilai kebenaran konjungsi dapat kita umpamakan seperti dua bola lampu yang dipasang dengan rangkaian seri, jika kedua saklar tertutup (On) maka kedua lampu menyala maka pernyataan bernilai benar, jika salah satu atau kedua saklar terbuka (Off) maka kedua lampu padam maka pernyataan bernilai salah.

2. Disjungsi ("atau").

Keduanya salah maka nilai kebenarannya salah selain itu benar. Nilai kebenaran disjungsi dapat kita umpamakan seperti dua bola lampu yang dipasang dengan rangkaian paralel, jika kedua saklar terbuka (Off) maka kedua lampu padam maka pernyataan bernilai salah, jika salah satu atau kedua saklar tertutup (On) maka kedua lampu menyala maka pernyataan bernilai benar.

3. Implikasi ("jika ... maka ...").

Nilai kebenaran implikasi dapat di ilustasikan dengan kalimat dalam kehidupan seharihari, yaitu:

a. Jika naik kereta maka beli tiket. Sudah sepantasnya apabila naik kereta membeli tiket maka pernyatan benar.

b. Jika naik kereta maka tidak beli tiket. Apabila naik kereta tidak membeli tiket maka tidak boleh, jadi pernyatan salah.

c. Jika tidak naik kereta maka beli tiket. Apabila tidak naik kereta membeli tiket tidak apa-apa maka pernyatan benar. 
d. Jika tidak naik kereta maka tidak beli tiket. Sudah sepantasnya apabila tidak naik kereta, tidak membeli tiket maka pernyatan benar.

4. Biimplikasi ( . . jika dan hanya jika . . .).

Nilai kebenaran biimplikasi dapat di ilustasikan dengan kalimat dalam kehidupan sehari-hari, yaitu:

a. Matahari terbit dari Timur jika dan hanya jika matahari terbenam di Barat. Maka pernyataan benar.

b. Matahari tidak terbit dari Timur jika dan hanya jika matahari tidak terbenam di Barat. Maka pernyataan benar.

c. Matahari tidak terbit dari Timur jika dan hanya jika matahari terbenam di Barat. Maka pernyataan salah.

d. Matahari terbit dari Timur jika dan hanya jika matahari tidak terbenam di Barat. Maka pernyataan salah.

\section{Analisis Kesulitan Belajar Berdasarkan Faktor Penyebab}

1. Faktor Fisiologis

Secara fisik siswa mengalami gangguan pada mata, dimana dia tidak dapat melihat sesuatu secara fokus. Pandangannya kelihatan jauh dari obyek yang seharusnya dilihat. Solusi yang diberikan guru adalah siswa ditempatkan di bangku paling depan sehingga memudahkan dia membaca tulisan.

\section{Faktor Sosial}

Sebagian besar siswa di SMK Muhammadiyah 3 Klaten Utara adalah ekonomi menengah ke bawah. Siswa merupakan anak yang pendiam dan tertutup, diduga ada permasalahan yang terjadi di rumah. Solusi yang diberikan siswa diberi motivasi belajar dan guru bekerja sama dengan orang tua siswa untuk membantu memberikan motivasi belajar kepada anaknya.

\section{Faktor Emosional}

Berdasarkan pengamatan guru terhadap siswa dimungkinkan bahwa yang mempengaruhi emosional siswa mengerjakan soal adalah adanya tekanan dari orang lain seperti teman dekat, orang tua atau lingkungan sekitarnya sehingga menyebabkan siswa mudah gugup dalam mengerjakan soal. Solusi yang ditempuh adalah dengan melakukan pendekatan terhadap siswa melalui guru bimbingan konseling. 


\section{Faktor Intelektual}

Dari penjaringan siswa di SMK Muhammadiyah 3 Klaten Utara tanpa tes masuk, maka sebagian besar intelektual siswa berada pada kategori menengah ke bawah. Solusi yang dapat ditempuh adalah dengan mengurangi kecepatan dalam pembelajaran matematika, artinya siswa paham terlebih dahulu materi tertentu baru dilanjutkan materi yang selanjutnya.

5. Faktor Pedagogik

Selama ini pembelajaran matematika di SMK Muhammadiyah 3 Klaten Utara menggunakan metode langsung yang menuntut keaktifan guru dan siswa hanya pasif. Solusi yang dapat ditempuh guru mengubah metode mengajar dengan menekankan keaktifan siswa dan guru hanya sebagai fasilitator.

\section{KESIMPULAN}

Berdasarkan pembahasan diatas diperoleh kesimpulan terkait kesulitan siswa dalam menyelesaikan soal logika matematika sebagai berikut:

Kesulitan yang dialami siswa dalam menyelesaikan soal logika matematika:

1. Siswa kesulitan dalam menentukan ekuivalensi kalimat majemuk

2. Siswa kesulitan dalam menentukan kesimpulan dari 2 premis

3. Siswa kesulitan dalam menentukan nilai kebenaran kalimat majemuk.

Faktor penyebab kesulitan belajar matematika:

1. Faktor Fisiologis

Gangguan fisik pada siswa

2. Faktor Sosial

Kurang motivasi dari orang tua atau guru.

3. Faktor Emosional

Tekanan dari orang lain seperti teman dekat, orang tua atau lingkungan sekitarnya

4. Faktor Intelektual

Intelektual siswa berada pada kategori menengah ke bawah.

5. Faktor Pedagogik

Metode mengajar yang digunakan metode langsung yang menuntut keaktifan guru dan siswa hanya pasif. 
Alternatif pemecahan dalam mengatasi kesulitan siswa dalam menyelesaikan soal logika matematika antara lain :

1. Memberikan pengertian kepada siswa apabila dalam logika matematika tidak dihafalkan satu persatu tetapi perlu pemahaman konsep logika matematika.

2. Memberikan latihan-latihan soal yang lebih banyak tentang pengambilan keputusan dari dua premis.

3. Memberikan alternatif untuk memudahkan siswa memahami konsep nilai kebenaran dengan menghubungkan dengan kalimat dalam kehidupan sehari - hari.

4. Bekerjasama dengan orang tua untuk memberi motivasi siswa.

5. Melakukan pendekatan terhadap siswa

6. Mengubah metode pembelajaran yang menekankan keaktifan siswa.

\section{DAFTAR PUSTAKA}

Cooney, Davis \& Henderson (1975). Dynamics of Teaching Secondary School Mathematics. Boston: Hougton Mifflin Company.

http://id.shvoong.com/exact-sciences/statistics/2114299-pengertian-logika/ diambil tanggal 10 November 2018.

p4tkmatematika.org/fasilitasi/22-diagnosis-kesulitan-belajar-matematika-smp-Rachmad.pdf diambil tanggal 29 Agustus 2018.

Widdiharto, Rachmadi (2004) Teknik Diagnosis dan Remidi Kesulitan Dalam Pembelajaran Matematika SMP, Paket Pembinaan Penataran, PPPG Matematika Yogyakarta. www.docstoc.com/docs/63868963/Logika-SMK diambil tanggal 14 Desember 2018. 